\title{
Coordinated localisation of mucins and trefoil peptides in the ulcer associated cell lineage and the gastrointestinal mucosa
}

R J Longman, J Douthwaite, P A Sylvester, R Poulsom, A P Corfield, M G Thomas, N A Wright

\begin{abstract}
Background and aims-Trefoil factor family (TFF) peptides and the chromosome $11 \mathrm{p} 15.5$ mucin glycoproteins are expressed and secreted in a site specific fashion along the length of the gastrointestinal tract. Evidence for coexpression of mucins and trefoil peptides has been suggested in numerous gastrointestinal mucosal pathologies. The ulcer associated cell lineage (UACL) occurs at sites of chronic ulceration in Crohn's disease, expresses all three trefoil peptides, and is implicated in mucosal restitution. We tested the hypothesis that individual trefoil peptides are uniquely localised with specific mucins in the UACL and normal gastrointestinal epithelia.
\end{abstract}

Methods-Expression of mucin genes in the UACL from small bowel tissue of patients with Crohn's disease was detected by in situ hybridisation, and localisation of the products by immunohistochemistry. Colocalisation of mucins and trefoil peptides was demonstrated by immunofluorescent colabelling in UACL and normal gastrointestinal epithelia.

Department of

Surgery, Bristol Royal

Infirmary, Bristol

BS2 8HW, UK

$\mathrm{R} \mathrm{J} \mathrm{Longman}$

J Douthwaite

P A Sylvester

M G Thomas

Histopathology Unit, Imperial Cancer

Research Fund, London WC2A 3PX, UK

R Poulsom

N A Wright

University

Department of

Medicine, Bristol

Royal Infirmary,

Bristol BS2 8HW, UK

A P Corfield

Department of

Histopathology, Royal

Postgraduate Medical

School, London

W12 0HS, UK

N A Wright

Correspondence to: Mr R J Longman.

Rob.Longman@bristol.ac.uk

Accepted for publication 23 May 2000 mucins (MUC1-4, 5AC, 5B, 6-8, 11, and 12) can be classified broadly into two groups: secreted mucins and membrane bound mucins. ${ }^{1-12}$ Within the gastrointestinal tract mucin glycoproteins are expressed in a site specific fashion. ${ }^{13}$ The small bowel normally expresses the mucins MUC1, MUC2, MUC3, MUC4, and MUC1 1, ${ }^{12-14}$ of which MUC2 is the predominant secreted mucin glycoprotein. ${ }^{15}$ There is a cluster of genes on chromosome $11 \mathrm{p} 15.5$ coding for four secreted mucins (MUC2, MUC5B, MUC5AC, and MUC6). ${ }^{16}$ MUC5AC, MUC5B, and MUC6 are not usually expressed by normal small bowel mucosa. ${ }^{13}{ }^{17}$ MUC5B is expressed normally in salivary gland tissue and gall bladder ${ }^{17}{ }^{18}$ whereas MUC6 is expressed in the stomach and Brunner's gland acini, and MUC5AC in the stomach. ${ }^{1{ }^{17} 19-21}$

The ulcer associated cell lineage (UACL) is a unique glandular structure occurring at sites of chronic gastrointestinal ulceration, commonly found at the borders of small bowel Crohn's ulcers and gastroduodenal ulceration. ${ }^{22}{ }^{23}$ In the small bowel the UACL evolves as a bud from the base of intestinal crypts, maturing to form a coiled acinar structure with a duct leading to the mucosal surface. ${ }^{22}$ Originally described as "pyloric" or "pseudo-pyloric" metaplasia, it has morphological similarities to both Brunner's glands ${ }^{24}$ and pyloric glands. ${ }^{25-27}$ The early development of the UACL following ulceration appears to be driven by extrusion of lineage cells rather than cellular proliferation, but in the mature UACL a distinct proliferative zone is apparent in the ductular portion from where cells migrate onto the indigenous mucosal surface. ${ }^{28} 29$ The UACL expresses a number of peptides implicated in the repair of damaged gastrointestinal mucosa, notably, epidermal growth factor and members of the trefoil peptide family, ${ }^{23}{ }^{30}$ now recognised as potent motogens in the gastrointestinal epithelium. ${ }^{31-33}$ The UACL, therefore, may play an important role in gastrointestinal mucosal healing.

The genes for trefoil factor family (TFF) peptides TFF1, TFF2, and TFF3 are clustered together on chromosome $21 \mathrm{q} 22.3 .{ }^{34}$ They are a unique group of small proteins implicated in

Abbreviations used in this paper: UACL, ulcer associated cell lineage; TFF, trefoil factor family; VNTR, variable number tandem repeat; PBS, phosphate buffered saline; DEPC, diethylpyrocarbonate; FITC, fluorescein isothiocyanate; TRITC, tetramethylrhodamine isothiocyanate. 
the process of restitution following mucosal injury. These peptides are expressed in a site specific pattern within normal human gastrointestinal epithelium; TFF1 throughout the stomach in foveolar epithelial surface cells, ${ }^{35} 36$ TFF2 in the distal stomach and in the acini of Brunner's glands in the duodenum, ${ }^{36-38}$ and TFF3 by goblet cells along the length of the small and large intestine. ${ }^{39} 40$ Trefoil peptides are localised within mucin granules in mucous secreting epithelial cells. ${ }^{28}$ It is currently unclear if the motogenic action of trefoil peptides on gastrointestinal epithelial cells is mediated via a receptor ${ }^{41}$ or through an interaction with mucins, ${ }^{42}$ or both. Recently, TFF1 has been shown to interact with the von Willebrand factor $\mathrm{C}$ cysteine rich domains that are present within the low glycosylated nonvariable number tandem repeat (VNTR) regions of muc 2 and muc5AC in the mouse. ${ }^{43}$ These von Willebrand factor $\mathrm{C}$ domains are present in all human chromosome 11 secreted mucins. With respect to possible mucin-trefoil peptide interactions, we have proposed that individual trefoil peptides are uniquely associated with specific mucin glycoproteins, possibly essential for mutual functional roles. ${ }^{28} \mathrm{We}$ examined this hypothesis by studying mucin gene expression, and mucin and trefoil peptide localisation in the UACL and normal gastrointestinal mucosa.

\section{Materials and methods}

\section{TISSUE SPECIMENS}

Formalin fixed, paraffin embedded archival tissue obtained from 17 patients who had undergone intestinal resection for active Crohn's disease of the small bowel were studied, together with tissues of normal gastric antrum $(n=5)$, body $(n=3)$, fundus $(n=2)$ and pylorus $(n=2)$, Brunner's glands in the proximal duodenum $(n=5)$, non-inflamed gall bladder $(n=3)$, jejunum $(n=2)$, ileum $(n=4)$, and colon $(n=11)$. Tissues from the main bronchus, submandibular salivary gland, and breast carcinomas were used as controls.

The presence of the UACL in small bowel mucosa from patients with Crohn's disease was confirmed by histological examination following standard haematoxylin and eosin staining, periodic acid Schiff/alcian blue staining, and high iron diamine/alcian blue staining.

MUCIN IMMUNOHISTOCHEMISTRY

Tissue sections of $5 \mu \mathrm{m}$ thickness were cut onto poly-L-lysine coated slides. Tissue sections were dewaxed in xylene and rehydrated through decreasing concentrations of alcohols. Sections were heated in a domestic pressure cooker at $121^{\circ} \mathrm{C}$ for two minutes while immersed in $10 \mathrm{mmol} / 1$ citrate buffer ( $\mathrm{pH} \mathrm{6.0)}$. For MUC2 staining only, tissues were reduced by a 30 minute incubation at $37^{\circ} \mathrm{C}$ with 10 $\mathrm{mmol} / 1$ dithiothreitol in $10 \mathrm{mmol} / 1$ Tris $\mathrm{HCl}$ (pH 8.0). Endogenous peroxidase activity was blocked with $3 \%$ hydrogen peroxide solution. Sections were stained for MUC2, MUC5AC, MUC5B, and MUC6 using polyclonal antibodies raised in rabbits against synthetic peptide sequences derived from human mucins (table 1). Primary antibodies diluted in phosphate buffered saline (PBS) were incubated with the tissues for 16 hours at $4^{\circ} \mathrm{C}$. PBS was substituted for each primary antibody on all tissues as a negative control. The second layer was a horseradish peroxidase conjugated goat antirabbit IgG antibody (Dako, High Wycombe, Bucks, UK) added at a 1:100 dilution in PBS and incubated for one hour at room temperature. A brown reaction product was obtained using $0.6 \mathrm{mg} / \mathrm{ml} \quad$ 3,3'diaminobenzidine with $0.03 \%$ (v/v) $\mathrm{H}_{2} \mathrm{O}_{2}$ (Sigma, Poole, Dorset, UK) and sections were counterstained with haematoxylin, before dehydration and mounting. Scoring of tissue sections for immunostaining was performed by conventional light microscopy. Maximal intensity of staining was scored on a scale of $0(0,+,++$, and +++ ) to 3 by two independent observers. Each structural feature of the UACL, namely acini, proximal ducts, distal ducts, and luminal surface cells was scored separately for each tissue section.

MUCIN MRNA IN SITU HYBRIDISATION

Specific 48-mer oligonucleotide probes directed against VNTR domains of the mucin gene mRNAs were end labelled with ${ }^{35} \mathrm{~S}$-deoxyadenosine triphosphate (Amersham Life Science, Amersham, Bucks, UK) by a terminal deoxynucleotidyltransferase kit (Boehringer Mannheim, Lewes, East Sussex, UK) (table 2). Probes were purified using a QIAquick nucleotide removal kit (Qiagen Ltd, Crawley, West Sussex, UK).

In situ hybridisation was performed on $5 \mu \mathrm{m}$ tissue sections mounted on gelatine coated slides. Slides were dewaxed in xylene and rehydrated through decreasing concentrations of alcohols to $0.1 \%$ diethylpyrocarbonate (DEPC) treated water. Protein unmasking was

Table 1 Human mucin and trefoil peptide antibodies. Characteristics of antibodies and dilutions used for immunohistochemical methodologies

\begin{tabular}{|c|c|c|c|c|}
\hline & Antibody & Epitope & Dilutions & Reference \\
\hline \multicolumn{5}{|l|}{ Mucin } \\
\hline MUC2 & LUM2-3 & C terminal end of non-VNTR domain & $1: 3000$ & Hovenberg et $a l^{44}$ \\
\hline MUC5AC & LUM5-1 & $\begin{array}{l}\mathrm{C} \text { terminal region, and tandem repeat } \\
\text { region flanking domain }\end{array}$ & $1: 800$ & Hovenberg et al ${ }^{46}$ \\
\hline MUC5B & MAN-5B1 & Non-VNTR domain, low glycosylated region & $1: 2500$ & Thornton $e t a l^{45}$ \\
\hline MUC6 & GPEP24 & VNTR domain, glycosylation dependent region & $1: 1000$ & * \\
\hline \multicolumn{5}{|l|}{ Trefoil } \\
\hline TFF1 & $\mathrm{pS} 2$ (GE2) 28AA & $\mathrm{C}$ terminal domain & $1: 2000$ & Rio et $a l^{47}$ \\
\hline TFF2 & Anti-hSP & C terminal domain & $1: 5$ & Elia $e t a l^{48}$ \\
\hline TFF3 & HM:169 & $\mathrm{C}$ terminal domain & $1: 500$ & Podolsky et $a l^{40}$ \\
\hline
\end{tabular}

VNTR, variable number tandem repeat.

$\star$ Personal communication: Dr I Carstedt, Lund, Sweden. 
Table 2 Human mucin and $\beta$-actin 48-mer probe oligonucleotide sequences

\begin{tabular}{|c|c|}
\hline Mucin & Oligonucleotide sequence \\
\hline MUC2 & ${ }^{5}$ GGT CTG TGT GCC GGT GGG TGT TGG GGT TGG GGT CAC CGT GGT GGT GGT ${ }^{3}$ \\
\hline MUC5AC & '5'AG GGC AGA AGT TGT GCT CGT TGT GGG AGC AGA GGT TGT GCT GGT TGT ${ }^{\prime \prime}$ \\
\hline MUC5B & 5'TGT GGT CAG CTC TGT GAG GAT CCA GGT CGT CCC CGG AGT GGA GGA GGG ${ }^{3 \prime}$ \\
\hline MUC6 & ${ }^{5}$ CAG CAC AGC CAA AAC CTC TAC ATC CCT CCA TCA CAT GCT TCC TCC ACA \\
\hline$\beta$-actin & ${ }^{5}$ ATG TCC ACG TCG CAC TTC ATG ATC GAG TTG AAG GTG GTC TCG TGG ATG ${ }^{3 \prime}$ \\
\hline
\end{tabular}

All mucin oligoprobes are directed against unique sequences within the variable number tandem repeat domains of the human mucin genes. ${ }^{6} 17$

performed by incubation with $5 \mu \mathrm{g} / \mathrm{ml}$ of proteinase $\mathrm{K}$ solution in $50 \mathrm{mmol} / \mathrm{l}$ Tris $\mathrm{HCl}$ $(\mathrm{pH} 7.5)$ for 20 minutes at $37^{\circ} \mathrm{C}$. Following a brief wash in DEPC treated water and PBS, tissues were acetylated with $0.25 \%$ acetic anhydride (v/v) in $0.9 \%$ sodium chloride $(\mathrm{w} / \mathrm{v})$ and $0.1 \mathrm{~mol} / 1$ triethanolamine $(\mathrm{pH} 8.0)$ for 10 minutes at room temperature and subsequently dehydrated through increasing concentrations of alcohols, before delipidisation in chloroform for five minutes. Tissues were again rehydrated through alcohols to DEPC treated water, and finally air dried at room temperature.

Hybridisations with oligonucleotide probes to MUC2, MUC5B, MUC5AC, and MUC6 mRNAs were performed, and to $\beta$-actin mRNA as a control. Hybridisation was performed with application of $60-90 \mu 1$ of hybridisation buffer containing $2 \times 10^{5} \mathrm{cpm}$ of labelled probe to each section. The hybridisation buffer was composed of $50 \%$ deionised formamide $(\mathrm{v} / \mathrm{v}), \times 1$ Denhardt's solution, $10 \%$ dextran sulphate (v/v), $50 \mathrm{mmol} / 1$ dithiothreitol, 0.25 $\mathrm{mg} / \mathrm{ml}$ yeast tRNA, and $0.5 \mathrm{mg} / \mathrm{ml}$ sheared salmon sperm DNA in $\times 4$ SSC solution $(\times 1$ SSC contains $0.15 \mathrm{~mol} / 1$ sodium chloride; 15 $\mathrm{mmol} / \mathrm{l}$ sodium citrate; $\mathrm{pH}$ 7.0) made up with DEPC treated water. The sections were coverslipped and hybridised for 16 hours at $45^{\circ} \mathrm{C}$ in humidity chambers. Further controls consisted of prehybridisation digestion of duplicate tissue sections with $50 \mu \mathrm{g} / \mathrm{ml}$ RNAse A (Boehringer Mannheim) in $0.4 \mathrm{~mol} / 1 \mathrm{NaCl}, 5 \mathrm{mmol} / 1$ EDTA, and $10 \mathrm{mmol} / 1$ Tris $\mathrm{HCl}(\mathrm{pH} 7.5)$ for 30 minutes at $37^{\circ} \mathrm{C}$ followed by five stringent washes in $\times 2 \mathrm{SSC}$ at $65^{\circ} \mathrm{C}$ for 10 minutes each to remove cleaved RNA fragments.

Posthybridisation washes were as follows: (a) five brief washes in $\times 1$ SSC at room temperature, (b) four washes in $\times 1 \mathrm{SSC}$ at $57^{\circ} \mathrm{C}$ for 30 minutes each, (c) two washes in $\times 1$ SSC at room temperature for 30 minutes, and finally (d) five minute wash in distilled water to remove salts.

Slides were dipped in photographic emulsion (K5 gel emulsion; Ilford Ltd, Mobberley, Cheshire, UK) and exposed in a desiccated chamber at $4^{\circ} \mathrm{C}$ for three weeks, after which they were developed (Kodak D19 developing solution; Kodak, Hemel Hempstead, UK) before counterstaining with toluidine blue. Localisation of mucin mRNA was performed by examining the counterstained slides under light and dark field microscopy.

MUCIN AND TFF PEPTIDE IMMUNOFLUORESCENT COLABELLING

All tissue sections were cut, rehydrated, and pressure cooked as described above, without the need for endogenous peroxidase blockade. Tissues were first incubated with a 1:10 dilution of normal goat serum for one hour at room temperature. Sections were then incubated with mouse antihuman trefoil peptide monoclonal primary antibodies (table 1) for one hour at room temperature. Tissue sections were subsequently incubated with either fluorescein isothiocyanate (FITC) conjugated goat antimouse $\mathrm{Fab}_{2}$ fragment secondary antibody (Sigma) at a 1:15 dilution for TFF1 localisation, or FITC conjugated goat antimouse IgM secondary antibody (Dako) at a 1:100 dilution for TFF2 localisation, for one hour at room temperature. Sections were incubated overnight at $4^{\circ} \mathrm{C}$ with a $1: 10$ dilution of normal swine serum. Dilutions of the appropriate rabbit antimucin polyclonal antibodies (table 1) were added to the sections and incubated at room temperature for one hour. Finally, the sections were incubated with a 1:20 dilution of a tetramethylrhodamine isothiocyanate (TRITC) conjugated swine antirabbit secondary antibody (Dako) for one hour at room temperature. Dilutions of antibodies and sera were in PBS. All stages were interposed with three, five minute washes in PBS. Duplicate tissue sections were run simultaneously as controls by individually substituting each primary and secondary antibody with PBS. To control for unwanted antibody cross reactions, pairs of primary and secondary antibodies were also substituted with PBS. Sections were then mounted with Vectashield containing 4', 6-diamidino-2-phenylindole (DAPI) as a blue fluorescing nuclear counterstain (Vector Laboratories, Peterborough, UK). Sections were viewed using a Leica DM RB fluorescence microscope (Leica Microsystems Ltd, Milton Keynes, UK). The TFF3 antibody and all mucin antibodies are polyclonals raised in rabbits and subsequently any mucin and TFF3 fluorescent stainings were not performed as a colabelling procedure but as single stainings using the TRITC conjugated swine antirabbit secondary antibody, as described above.

\section{Results}

MUCIN GENE EXPRESSION IN THE ULCER

ASSOCIATED CELL LINEAGE

The UACL was identified on histological sections as buds or glandular structures arising from the base of small bowel crypts in the tissue sections from all 17 patients with active Crohn's disease. UACL glands were composed of cuboidal shaped epithelial cells with pale staining cytoplasm, small round nuclei situated at the basal poles of the cells, and the surface cells contained a double secretory vesicle 
pattern characteristic of this cell lineage. In 13 tissues exhibiting more mature UACL glands, ductal elements were identified leading towards the mucosal surface. In 11 tissues the
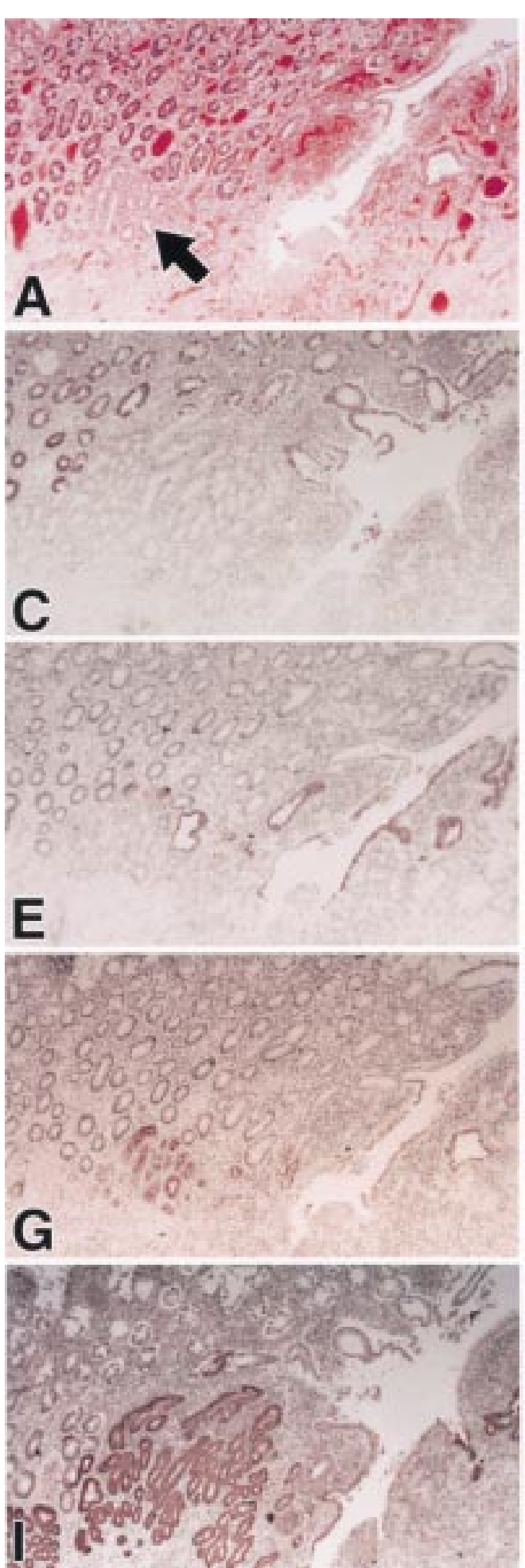

Figure 1 Sections of terminal ileum from a patient with active Crohn's disease showing tissue morphology and mucin gene expression. (A) Haematoxylin and eosin stain, with ulcer associated cell lineage (UACL) glands indicated by an arrow. (B) Periodic acid Schifflalcian blue stained goblet cell mucins blue/purple and UACL glands magenta. (C) MUC2 glycoprotein immunohistochemical localisation (brown) confined to goblet cells, corresponding to the pattern of expression of (D) MUC2 mRNA. (E, F) MUC5AC glycoprotein and $m R N A$ localised to some surface and upper ductular compartments of UACL glands. $(G, H) M U C 5 B$ glycoprotein and $m R N A$ localised to some surface and mid deep compartments of the UACL glands. (I, F) MUC6 glycoprotein and $m R N A$ are abundant in the acinar and ductular compartments of the UCAL, with some MUC6 glycoprotein also in the surface cells. All immunohistochemical sections were counterstained with haematoxylin, and all in situ hybridisation sections counterstained with toluidine blue. Original magnifications: $A-\mathcal{F} 50 \times$. 
Table 3 Immunohistological scoring of mucin gene product within the ulcer associated cell lineage (UACL)

\begin{tabular}{lllll}
\hline & MUC2 & MUC5AC & MUC5B & MUC6 \\
\hline Small bowel mucosa $(\mathrm{n}=17)$ & +++ & 0 & 0 & 0 \\
UACL acini $(\mathrm{n}=17)$ & 0 & 0 & ++ & +++ \\
UACL proximal ducts $(\mathrm{n}=17)$ & 0 & 0 & ++ & +++ \\
UACL distal ducts $(\mathrm{n}=13)$ & 0 & ++ & + & + \\
UACL surface cells $(\mathrm{n}=11)$ & 0 & ++ & + & 0 \\
\hline
\end{tabular}

Average scores of staining intensity on a scale of 0 to $3+$ for the mucins MUC2, 5AC, $5 \mathrm{~B}$, and 6 in small bowel Crohn's disease tissues exhibiting the UACL. UACL acini and UACL proximal ducts were identified in all 17 tissues examined while distal ductular components and luminal surface UACL structures were present in 13 and 11 tissues, respectively.

UACL stained positive using the periodic acid Schiff stain (fig 1B), suggesting the presence of relatively neutral mucins compared with the more acidic mucin staining pattern of the crypts of small bowel Crohn's mucosa with alcian blue. The UACL consistently demonstrated the presence of carboxylated mucin by positive staining with high iron diamine/alcian blue (data not shown) while the remaining small bowel mucosa exhibited a mixed picture with cells expressing sulphated and carboxylated glycoproteins.

Immunohistochemical localisation of MUC2, MUC5AC, MUC5B, and MUC6 secretory mucin glycoproteins was matched by expression of their corresponding mRNA (fig 1C-J). Expression of the human mucins MUC5B, MUC5AC, and MUC6 in small bowel tissue affected by active Crohn's disease was limited to the UACL in the 17 examples studied (table 3). MUC5AC was localised in the secretory vesicles and the cytoplasm of cells of the ductal portion of the UACL and where it had spread over the luminal surface (fig 1E) whereas MUC6 mRNA expression was limited to the acini (fig 1J) and where MUC6 staining was apparent only in the cytoplasm as a consequence of the VNTR directed antibody detect-

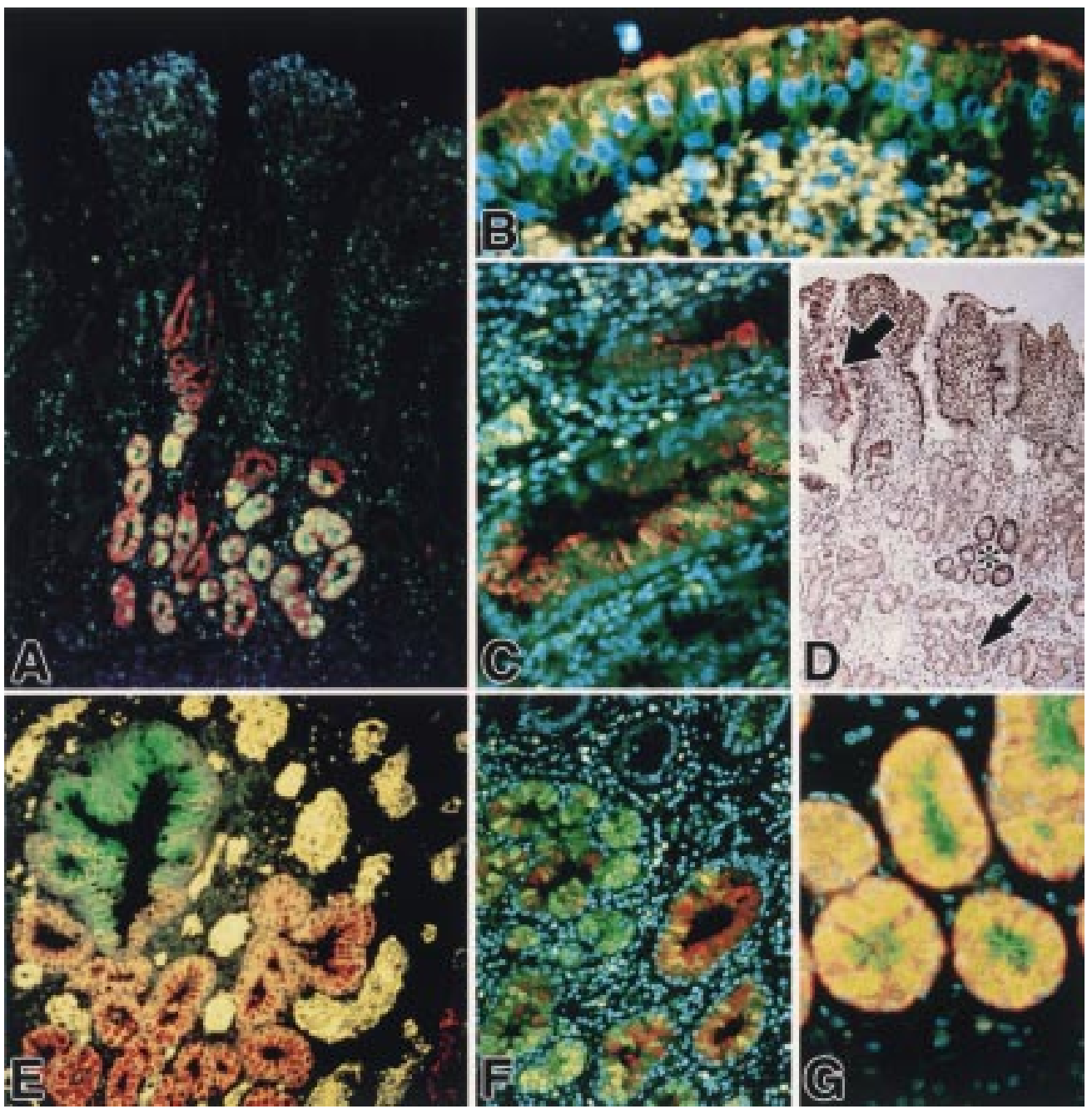

Figure 2 Fluorescent immunohistochemical localisation of mucin glycoproteins and trefoil factor family (TFF) peptides in ulcer associated cell lineage (UACL) glands. (A) TFF2 (green) appears to be confined to the acinar and lower ductular compartments; MUC6 (red) is seen throughout the acini and some ductular components; colocalisation is seen as orange-yellow in many acinar cells. Nuclei are counterstained blue with DAPI. $(B, C)$ TFF1 (green) and MUC5AC (red) are located in UACL surface cells $(B)$ and ducts $(C)$; colocalisation is frequent and seen as orange-yellow. Erythrocytes in the lamina propria autofluoresce an intense yellow (DAPI counterstain). (D) Conventional immunohistochemical localisation of TFF3 (brown) reveals strong staining in crypts (asterisk) and also in UACL (small arrow), particularly in the surface cells (large arrow) (haematoxylin counterstain). (E) TFF1 (green) and MUC6 (red) are present in opposing gradients; TFF1 is localised most strongly in the surface cells and upper ducts whereas MUC6 alone is present in acinar cells (red; bottom and right) and colocalisation (orange-yellow) is seen through the ducts. Erythrocytes in the lamina propria autofluoresce an intense yellow (weak DAPI counterstain). (F) TFF2 (green) and MUC5B (red) colocalise in some acinar and duct cells (DAPI counterstain). (G) TFF2 (green) and MUC6 (red) are both abundant in acinar cells of the UACL (DAPI counterstain). Original magnifications: A 100x; B, C, and G 400x; D 50×; E and F 200x. 
ing non-glycosylated mucin (fig 1I). MUC6 glycoprotein was weakly detected in UACL surface cells and was also evident in Brunner's glands and in the base of gastric glands in control tissues; conversely, these areas did not express MUC5AC. The surface mucosa of the
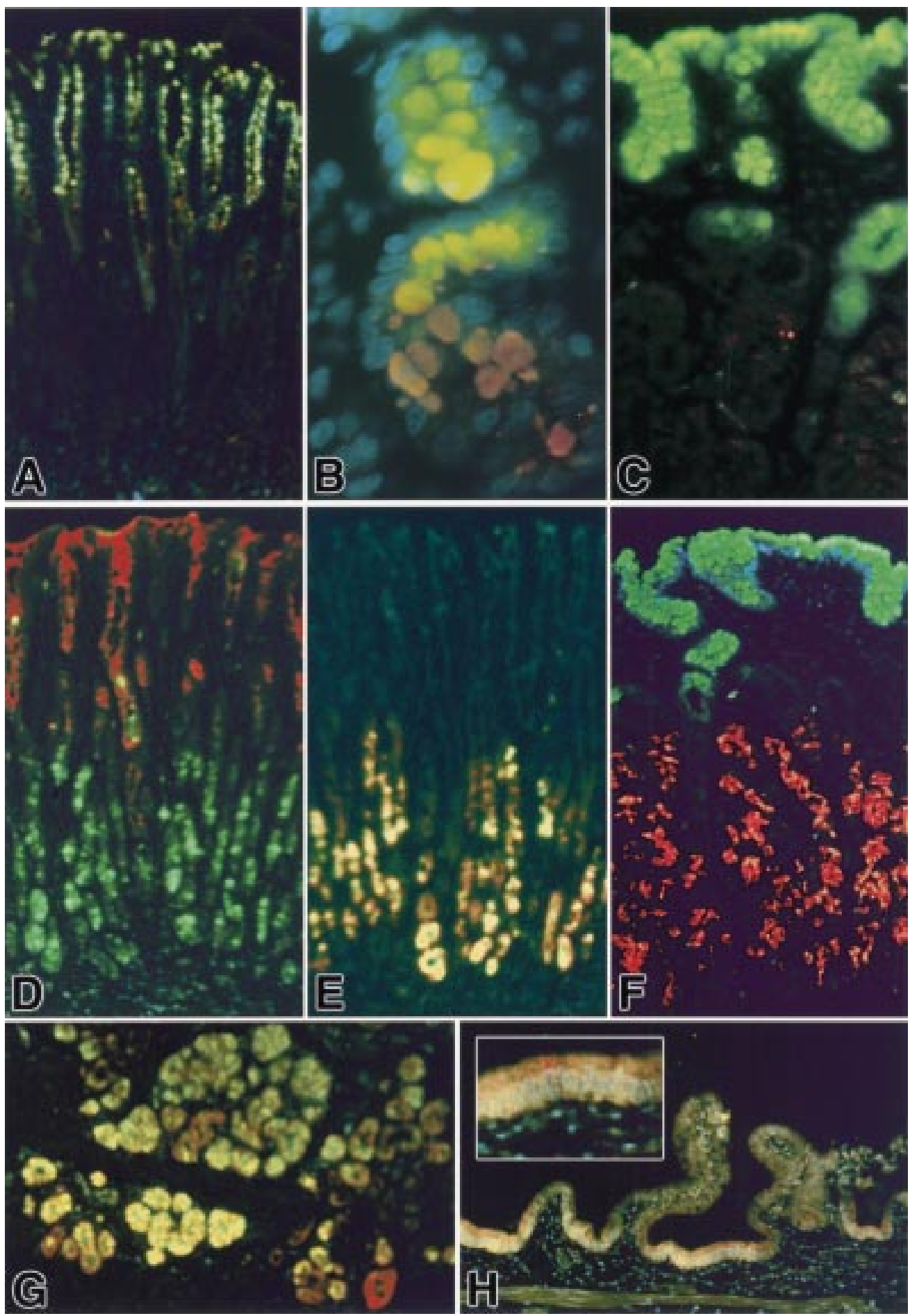

Figure 3 Fluorescent immunohistochemical localisation of mucin glycoproteins and trefoil factor family (TFF) peptides in the stomach, duodenum, and gall bladder. $(A, B)$ TFF1 (green) and MUC5AC (red) colocalised in the gastric surface epithelium; MUC5AC immunoreactivity continues deeper into the isthmus and neck region (DAPI counterstain). (C) TFF1 (green) appears abundant in gastric foveolar surface cells whereas MUC5B (red) appears weakly localised to some mucous neck cells (weak DAPI counterstain). (D) TFF2 (green) and MUC5AC (red) were mostly segregated, with TFF2 immunoreactivity abundant in basal parts of these gastric glands and MUC5AC glycoprotein abundant in the epithelium at the surface, isthmus, and neck. Colocalisation was infrequent (DAPI counterstain). (E) TFF2 (green) and MUC6 glycoprotein (red) were mostly colocalised and confined to the basal parts of these gastric glands. (F) TFF1 (green) and MUC6 glycoprotein (red) were mostly segregated, with TFF1 abundant in surface epithelium and MUC6 appearing confined to epithelium in the lower half of these gastric glands, including some unequivocal mucous neck cells (red; upper left) (DAPI counterstain). (G) TFF2 (green) and MUC6 glycoprotein (red) were abundant in epithelium in the acini of Brunner's glands of the duodenum, and are most often colocalised (weak DAPI counterstain). (H) TFF2 (green) and MUC6 glycoprotein (red) appear colocalised (orange-yellow) in some epithelium of this non-inflamed gall bladder. Inset shows enlargement of central region (DAPI counterstain). Original magnifications: $A, D, E, H$ 100x; B 400x; C 250x; F 200x. 
gastric antrum and pylorus, however, strongly expressed MUC5AC. The change from MUC6 to MUC5AC localisation across the UACL structure was strongly demarcated with a complete switch occurring between adjacent UACL cells. MUC5B mRNA was expressed throughout the UACL (fig $1 \mathrm{H}$ ), and MUC5B glycoprotein was localised to the secretory vesicles and cytoplasm of cells in both ductular and acinar structures of the UACL (fig 1G). In contrast, MUC2 mRNA expression was confined to the goblet cells of the indigenous small bowel mucosa (fig 1D), and MUC2 expression was absent from the UACL (fig 1C). A clear demarcation was identified at the luminal surface in tissues exhibiting UACL cells. At a discrete point where the morphological switch from cuboidal to columnar shaped phenotype was observed, mucin gene expression and mucin glycoprotein localisation changed correspondingly from MUC5AC to MUC2. Mismatch patterns of mucin gene mRNA localisation and mucin gene product localisation were evident. MUC5AC mRNA localisation within the surface component of the UACL was, on occasions, lacking while immunohistochemical staining showed strong reactivity (fig $1 \mathrm{E}, \mathrm{F}$ ). A simple mechanism to explain this discrepancy is that as UACL cells migrate upwards from the proliferative zone towards the luminal surface, the MUC5AC gene mRNA becomes detectable in cells of the lineage. Following further upward migration of lineage cells, expression of mRNA ceases, yet leaves detectable MUC5AC glycoprotein within such cells.

With colabelling studies it was evident that in the UACL acini MUC6 glycoprotein and TFF2 peptide were colocalised (fig 2A, G) while MUC5AC glycoprotein and TFF1 peptide were colocalised in the ductular and surface elements (fig 2B, C). A clear demarcation between trefoil peptide and mucin colocalisation patterns was present between the ductular and acinar components of the UACL structure (fig 2E). MUC5B appeared to overlap across the UACL structure with both TFF1 (data not shown) and TFF2 (fig 2F). TFF3 peptide was also localised in a sporadic fashion throughout the UACL, as described previously for TFF3 $\mathrm{mRNA},{ }^{51}$ with the strongest immunoreactivity in the surface cells of the UACL (fig 2D).

MUCIN AND TFF PEPTIDE COLOCALISATION IN NORMAL GASTROINTESTINAL MUCOSA

In the gastric body, TFF1 and MUC5AC were located at the epithelial surface and in the foveolar pit area (fig 3A, B). TFF2 and MUC6 were found together from the mucous neck cells to the base of the gastric glands (fig $3 \mathrm{E}$ ). Moreover, in the gastric antrum, TFF1 peptide and MUC5AC glycoprotein were colocalised to the upper region of the glands, whereas TFF2 and MUC6 were confined to the gland bases (data not shown). Neither TFF3 nor MUC2 were detectable in the normal stomach. However, MUC5B glycoprotein was located in a narrow band across the neck region of the gastric body where cross over of TFF1 and TFF2 localisation occurred (fig 3C). The fun- dus of the stomach exhibited TFF1 and MUC5AC colocalisation at the very surface of the epithelium, and TFF2 and MUC6 colocalisation in fundic glands (data not shown). In the pyloric region of the stomach, colocalisation of TFF2 and MUC6 in the glands was identical to that seen in all the Brunner's gland tissues studied (fig 3G) with the surface epithelium characterised by a relative paucity of immunohistochemical staining for either TFF1 or MUC5AC. Clear segregation of TFF1 from MUC6 (fig 3F) and TFF2 from MUC5AC (fig 3D) was apparent throughout the regions of the stomach. The same patterns of colocalisation were evident in all gastric tissues studied. In the duodenum, TFF3 and MUC2 were localised to the goblet cell vesicles at the luminal surface, as was the pattern in the rest of the small bowel and the colorectum in all tissues studied (data not shown). In the three non-inflamed gall bladder tissues, sporadic localisation of TFF2 and MUC6 occurred (fig $3 \mathrm{H}$ ), and MUC5B glycoprotein appeared absent. MUC6 fluorescence in the gall bladder mucosa was identified in the secretory vesicles as well as in the cytoplasm. This may reflect reduced glycosylation of the MUC6 VNTR region in comparison with the acini of the UACL or antral glands of the stomach where MUC6 immunofluorescence was predominantly cytoplasmic (figs $2 \mathrm{G}, 3 \mathrm{G}$ ). While this is a phenomena of using a VNTR directed antibody to MUC6, confirmation of this finding could be identified with the additional use of a non-VNTR directed antibody that unfortunately was not available at the time of the study.

\section{Discussion}

The mucin expression profile of the UACL has not previously been determined. Despite morphological similarities with pyloric glands and Brunner's glands, ${ }^{24-27}$ the UACL expresses a different set of secreted mucins, namely MUC5AC, MUC5B, and MUC6. This mucin glycoprotein expression profile is concordant with the observations of Roberts and Stoddart ${ }^{49}$ who investigated the lectin binding profile of the UACL, with type A lectin staining pattern mimicking MUC6 expression and type B mimicking MUC5AC expression. This lectin binding pattern would suggest that mucin carbohydrate moieties are somewhat specific to individual mucin genes and is thus a reflection of the mucin gene expression profile across the UACL structure. The pattern of TFF gene expression in the UACL associated with Crohn's disease ulcers also reflects this mucin profile. $^{28}{ }^{50}$ TFF 1 is expressed solely by the more mature surface or distal ductular component of the UACL structure whereas TFF2 is expressed by the acinar and proximal duct structures. ${ }^{28} \mathrm{TFF} 3$, the sole trefoil peptide expressed by the normal small bowel mucosa, is found heterogeneously throughout the UACL glands as is its mRNA. ${ }^{51}$ The UACL is unique among mucosal phenotypes in expressing three secreted mucins of the chromosome 11 p15.5 genes and all three known trefoil peptides in close proximity. 
In normal gastrointestinal mucosal structures there is a general correlation between mucin glycoprotein and trefoil peptide gene expression. TFF1 segregates with MUC5AC in foveolar pit cells of the gastric body and superficial regions of antral glands. $\mathrm{TFF} 2$ is colocalised with MUC6 in gastric body mucous neck cells, deep antral glands, and Brunner's gland acini. In goblet cells of the small and large bowel, TFF3 is found together with MUC2.

We have demonstrated that MUC5AC is found closely associated with $\mathrm{TFF} 1$, and MUC6 with TFF2, and this appears to hold true for both normal gut epithelia and the UACL. Moreover, TFF3 and MUC2 were coexpressed in the large and small intestine within goblet cells. Similarly, MUC5B was expressed in the UACL and the gastric body in a region of overlap with TFF1 and TFF2. These findings are reiterated in several gastrointestinal pathologies. Recent work has suggested coexpression patterns of mucins and trefoils occurring in spasmolytic polypeptide expressing metaplasia ${ }^{52}$ and pseudo pyloric metaplasia of the stomach (authors' unpublished observations), Barrett's metaplasia of the oesophagus, ${ }^{53}$ and early diffuse gastric cancer (authors' unpublished observations). The finding of MUC5 $\mathrm{AC}^{54}$ and TFF $1^{55}$ neo expression in colorectal adenomas appears to confirm our hypothesis. Thus the pattern of mucin/trefoil peptide coordinated expression remains in metaplastic and early neoplastic gastrointestinal pathologies and would require the preservation of regulation between chromosome $11 \mathrm{p} 15.5$ and $21 \mathrm{q} 22.3$ regions.

There are however discrepancies. We found that MUC2 and TFF3 were generally associated, except in the UACL where TFF3 was expressed in the absence of MUC2 expression. In addition, MUC5B was expressed in the UACL and the gastric body without any known association with an individual trefoil peptide. MUC5B expression has previously been reported in the gall bladder and at lower levels in the colon. ${ }^{56}$ MUC5B expression in the gall bladder, however, may be linked to the presence of chronic inflammation. These anomalies are not explained by our hypothesis although it is possible that a further trefoil peptide which associates with MUC5B remains to be discovered. The results show that there is a degree of heterogeneity in cellular localisation of both mucins and trefoil peptides that may reflect variability in local cell populations due to differentiation, maturity, or responses to external stimuli. Furthermore, such heterogeneity can also be seen between epithelia of different anatomical sites and is likely to reflect both varying proportions of trefoil peptide and mucin glycoprotein expression by different epithelial cell populations and also differences between mucin glycosylation levels, as detected by the antibodies used in this study. This confirms the theory that not only do functional goblet cells, and indeed any gastrointestinal mucous secreting cells, maintain their phenotype as defined by their mucus content and production, but moreover help to define the heterogeneity of gastrointestinal epithelial cells. ${ }^{57}$ It is unlikely that the association between mucin and trefoil peptide expression is purely fortuitous, and underlines our previous suggestion that specific trefoil peptides interact with specific secreted mucin glycoproteins. A possible mechanism of trefoil peptide function is interaction with mucin molecules to stabilise the mucus gel. ${ }^{42}$ It is possible that trefoil peptides have to interact with specific mucins to produce this effect. However, there are as yet few data to support mucin glycoprotein/trefoil peptide interactions within the mucus gel. While TFF1 appears to interact with von Willebrand factor $\mathrm{C}$ domains present in the low glycosylated regions of murine muc2 and muc5AC proteins, the functional significance of this finding remains unknown. ${ }^{43}$ It may be possible that trefoil peptides are required for the control of mucin biosynthesis, glycosylation, vesicular packaging, mucus secretion, or protection of mucus degradation within the lumen.

In conclusion, we have demonstrated that the UACL has a unique pattern of mucin gene expression, and that chromosome $11 \mathrm{p} 15.5$ mucin gene expression appears to be broadly correlated with that of specific trefoil peptide genes. What manner of regulation is exerted on these genes to effect their coordinated expression has yet to be determined. The potential molecular interaction between trefoil peptides and mucin glycoproteins, whether a predominantly peptide/carbohydrate or a peptide/ peptide interaction, remains to be elucidated.

RJ Longman is supported by a research fellowship from the Royal College of Surgeons of England. This work was also funded by the Medical Research Committee of the Special Trustees for the United Bristol Healthcare Trust, and by the Imperial Cancer Research Fund. The authors wish to thank the European Union consortium (grant CEEBMH4-CT98-3222) for LUM2-3 and LUM5-1 antimucin antibody development, Dr I Carlstedt (Lund University, Lund, Sweden) for the generous gift of the GPEP24 antimucin antibody, Dr JK She the generous gift of the GPEP24 antimucin antibody, Dr JK Sheehan and Dr DJ Thornton (University of Manchester, Manchester, UK) for the generous gift of the MAN-5B1 antimucin antibody, and Professor DK Podolsky (Massachusetts General Hospital, Boston, USA) for the generous gift of the HM:169 anti-TFF3 anti-

1 Klomp LWJ, Van Rens L, Strous GJ. Cloning and analysis of human gastric cDNA reveals two types of conserved cysteine-rich domains. Biochem $\mathcal{f}$ 1995;308:831-8.

2 Gendler SJ, Lancater C, Taylor-Papadimitiou J, et al. Molecular cloning and expression of human tumorassociated polymorphic epithelial mucin. F Biol Chem 1990;265:15286-93.

3 Gum JR, Hicks JW, Swallow DM, et al. Molecular cloning of cDNAs derived from a novel human intestinal mucin gene. Biochem Biophys Res Comm 1990;171:407-15.

4 Porchet N, Ngyen van Cong J, Dufosse J, et al. Molecular cloning and chromosomal localization of a novel human tracheo-bronchial mucin cDNA containing tandem repeated sequences of 48 base pairs. Biochem Biophys Res Comm 1991;175:414-22.

5 Dufosse J, Porchet N, Audie JP, et al. Degenerate 87-base-pair tandem repeats create hydrophilic/ hydrophobic alternating domains in human peptides mapped to 11p15. Biochem f 1993;293:329-37.

6 Toribara NW, Roberton AM, Ho SB, et al. Human gastric mucin. Identification of a unique species by expression cloning. F Biol Chem 1993;268:5879-85.

7 Bobek LA, Tsai H, Biesbrock RA, et al. Molecular cloning, sequence, and specificity of expression of the gene encoding the low molecular weight human salivary mucin (MUC7). F Biol Chem 1993;268:20563-9.

8 Gum JR, Hicks JW, Toribara NW, et al. Molecular cloning of human intestinal mucin (MUC2) cDNA. I Biol Chem 1994;269:2440-6.

9 Shankar V, Gilmore MS, Elkins RC, et al. A novel human airway mucin cDNA encodes a protein with unique tandem-repeat organization. Biochem $\mathcal{F}$ 1994;300:295-8.

10 Meezerman DP, Charles P, Daskal E, et al. Cloning and analysis of a cDNA encoding major airway glycoprotein, 
human tracheobronchial mucin (MUC5). 7 Biol Chem 1994;269:12932-9.

11 Guyonnet-Duperat V, Audie J-P, Debailleul V, et al. Characterization of the human mucin gene MUC5AC: a consensus cysteine-rich domain for $11 \mathrm{p} 15$ mucin genes? Biochem f 1995;305:211-19.

12 Williams SJ, McGuckin MA, Gotley DC, et al. Two novel mucin genes down-regulated in colorectal cancer identified by differential display. Cancer Res 1999;59:4083-9.

13 van Klinken BJW, Dekker J, Buller HA, et al. Biosynthesis of mucins (MUC2-6) along the longitudinal axis of the human gastrointestinal tract. Am f Physiol 1997; 273(Gastrointest Liver Physiol:36):G296-302.

14 Weiss AA, Babyatsky MW, Ogata S, et al. Expression of MUC2 and MUC3 mRNA in human normal, malignant, and inflammatory intestinal tissues. $f$ Histochem Cytochem 1996;44:1161-6.

15 Tytgat KMAJ, Buller HA, Opdam FJM, et al. Biosynthesis of human colonic mucin: MUC2 is the predominant secreof human colonic mucin: MUC2 is the predomina

16 Pigny P, Guyonnet-Duperat V, Hill AS, et al. Human mucin genes assigned to $11 \mathrm{p} 15.5$; identification and organization of a cluster of genes. Genomics 1996;38:340-52.

17 Audie JP, Janin A, Porchet N, et al. Expression of human mucin genes in respiratory, digestive, and reproductive tracts ascertained by in situ hybridisation. F Histochem Cytochem 1993;41:1479-85.

18 van Klinken BJ-W, Dekker J, van Gool SA, et al. MUC5B is the prominent mucin in the gallbladder and is also expressed in a subset of colonic goblet cells. Am f Physio 1998;274:G871-8.

19 Klomp LWJ, Van Rens L, Strous GJ. Identification of a human gastric mucin precursor; N-linked glycosylation and oligomerization. Biochem f 1994;304:693-8.

20 De Bolos C, Garrido M, Real FX. MUC6 apomucin shows distinct normal tissue distribution which correlates with Lewis antigen expression in the stomach. Gastroenterology 1995;109:723-34

21 Ho SB, Roberton AM, Shekels LL, et al. Expression cloning of gastric mucin complementary DNA and localization of of gastric mucin complementary DNA and localization of

22 Wright NA, Pike C, Elia G. Induction of a novel epidermal growth factor-secreting cell lineage by mucosal ulceration growth factor-secreting cell lineage by mucosal ulcert
in gastrointestinal stem cells. Nature 1990;343:82-5.

23 Wright NA, Poulsom R, Stamp GWH, et al. Epidermal growth factor (EGF/URO) induces expression of regulatory peptides in damaged human gastrointestinal tissues. $\mathcal{F}$ Pathol 1990;162:279-84

24 Kawel CA, Tesluk H. Brunner-type glands in regional enteritis. Gastroenterology 1955;28:210-21.

25 Liber AF. Aberrant pyloric glands in regional ileitis. Arch Pathol 1951;51:205-19.

26 Lee F. Pyloric metaplasia in the small intestine. 7 Pathol Bacteriol 1964;87:267-79.

27 Bloom W, Fawcett DW. A textbook of histology. Philadelphia: WB Saunders, 1975:652.

28 Ahnen DJ, Poulsom R, Stamp GWH, et al. The ulcerassociated cell lineage (UACL) reiterates the Brunner's gland differentiation but acquires the proliferative organigland differentiation but acquires the proliferative organi

29 Patel K, Hanby AM, Ahnen DJ, et al. The kinetic organization of the ulcer-associated cell lineage (UACL): delineation of a novel putative stem-cell region. Epith Cell Bio 1994;3:156-60

30 Wright NA, Poulsom R, Stamp G, et al. Trefoil peptide gene tory bowel disease. Gastroenterology 1993;104:12-20.

31 Dignass A, Lynch-Devaney K, Kindon H, et al. Trefoil peptides promote epithelial migration through a transforming growth factor beta-independent pathway. 7 Clin Invest 1994;94:376-83.

32 Kato K, Chen MC, Lehman F, et al. Trefoil peptides, IGF-1 and basic FGF stimulate restitution in primary cultures of canine oxyntic mucosal cells. Gastroenterology 1995;108: A130.

33 Playford RJ, Marchbank T, Chinery R, et al. Human spasmolytic polypeptide is a cytoprotective agent that spasmolytic polypeptide is a cytoprotective agent that
stimulates cell migration. Gastroenterology 1995;108:106stim

34 Seib T, Blin T, Hilgert $\mathrm{K}$, et al. The three human trefoil genes TFF1, TFF2, and TFF3 are located within a region of $55 \mathrm{~kb}$ on chromosome 21q22.3. Genomics 1997;40:2002 .
35 Rio M, Bellocq JP, Daniel JY, et al. Breast cancer-associated pS2 protein: synthesis and secretion by normal stomach Science 1988;241:705-8.

36 Hanby AM, Poulsom R, Singh S, et al. Spasmolytic polypeptide is a major antral peptide: distribution of the trefoil peptides human spasmolytic polypeptide and $\mathrm{pS} 2$ in the stomach. Gastroenterology 1993;105:1110-16.

37 Tomasetto C, Rio M-C, Gautier C, et al. hSP, the domainduplicated homolog of $\mathrm{pS} 2$ protein, is co-expressed with pS2 in stomach but not in breast carcinoma. Eur Mol Biol Organ f 1990;9:407-14.

38 Hanby AM, Poulsom R, Elia G, et al. The expression of trefoil peptides pS2 and human spasmolytic polypeptide (hSP) in "gastric metaplasia" of the proximal duodenum: implications for the nature of "gastric metaplasia". 7 Pathol 1993;169:355-60.

39 Suemori S, Lynch-Devaney K, Podolsky DK. Identification and characterization of rat intestinal trefoil factor: tissueand cell-specific member of the trefoil protein family. Proc Natl Acad Sci USA 1991;88:11017-21.

40 Podolsky DK, Lynch-Devaney K, Stow JL, et al. Identification of human intestinal trefoil factor: goblet cell-specific expression of a peptide for targeted apical secretion. F Biol

41 Efstathiou JA, Noda M, Rowan A, et al. Intestinal trefoil factor controls the expression of the adenomatous polyposis coli-catenin and the E-cadherin-catenin complexes in human colon carcinoma cells. Proc Natl Acad Sci USA 1998;95:3122-7.

42 Kindon H, Pothoulakis C, Thim L, et al. Trefoil peptide protection of intestinal epithelial barrier function: cooperative interaction with mucin glycoprotein. Gastroenterology 1995;109:516-23.

43 Tomasetto C, Masson R, Linares JL, et al. pS2/TFF1 interacts directly with the VWFC cysteine-rich domains of mucins. Gastroenterology 2000;118:70-80.

44 Hovenberg HW, Davies JR, Herrmann A, et al. MUC5AC, but not MUC2, is a prominent mucin in respiratory secretions. Glycoconjugate f 1996;13:839-47.

45 Thornton DJ, Howard M, Khan N, et al. Identification of two glycoforms of the MUC5B mucin in human respiratory mucus. Evidence for a cysteine-rich sequence repeated within the molecule. F Biol Chem 1997;272:9561-6.

46 Hovenberg HW, Davies JR, Carlstedt I. Different mucins are produced by the surface epithelium and the submucosa in human trachea: identification of MUC5AC as a major mucin from the goblet cells. Biochem f 1996;318:319-24.

47 Rio M-C, Chenard MP, Wolf C, et al. Induction of pS2 and hSP genes as markers of mucosal ulceration of the digestive tract. Gastroenterology 1991;100:375-9.

48 Elia G, Hanby A, Poulsom R, et al. A putative human spasmolytic polypeptide (hSP) antibody and its staining patter in gastrointestinal epithelium. Gut 1992;33(suppl):45.

49 Roberts ISD, Stoddart RW. Ulcer-associated cell lineage ('pyloric metaplasia') in Crohn's disease: a lectin histo('pyloric metaplasia') in Crohn's disease:
chemical study. $\mathcal{F}$ Pathol 1993;171:13-19.

50 Poulsom R, Chinery R, Sarraf C, et al. Trefoil peptide gene expression in small intestinal Crohn's disease and dietary adaptation. F Clin Gastroenterol 1993;17(suppl 1):S78-91.

51 Hauser F, Poulsom R, Chinery R, et al. Hp1.B, a human P-domain peptide homologous with rat intestinal trefoil P-domain peptide homologous with rat intestinal trefoil the uterus. Proc Natl Acad Sci USA 1993;90:6961-5.

52 Schmidt PH, Lee JR, Joshi V, et al. Identification of a metaplastic cell lineage associated with human gastric adenocarcinoma. Lab Invest 1999;79:639-46.

53 Labouvie C, Machado JC, Carniero F, et al N. Differential expression of mucins and trefoil peptides in native epithelium, Barrett's metaplasia and squamous cell carcinoma of the oesophagus. F Cancer Res Clin Oncol 1999;125: 71-6.

54 Buisine MP, Janin A, Maunory V, et al. Aberrant expression of a human mucin gene (MUC5AC) in rectosigmoid villous adenoma. Gastroenterology 1996;110:84-91.

55 Henry JA, Bennett MK, Pigott NH, et al. Expression of the $\mathrm{pNR}-1 / \mathrm{pS} 2$ protein in diverse human epithelial tumours. pNR-1/pS2 protein in diverse

56 van Klinken BJ-W, Dekker J, van Gool SA, et al. MUC5B is the prominent mucin in the human gallbladder and is also expressed in a subset of colonic goblet cells. Am f Physiol 1998:274:G871-8.

57 Podolsky DK. The colonic goblet cell and glycoprotein heterogeneity. Immunol Invest 1989;18:485-97. 